\section{MATHEMATICAL MODELLING AND CONCEPTUAL DESIGN OF NOVEL AUTOMATIC TYRE INFLATING SYSTEM}

Sivaraosa*, K. Umeshb, M. S. Salleha, D. Sivakumarc, R. Izamshaha, M. A. M. Alia

aFakulti Kejuruteraan Pembuatan, Universiti Teknikal Malaysia Melaka 76100, Durian Tunggal, Melaka, Malaysia

bMechanical Engineering Department ASET, Amity University Uttar

Pradesh, Noida, India

cFakulti Kejuruteraan Mekanikal, Universiti Teknikal Malaysia Melaka 76100, Durian Tunggal, Melaka, Malaysia
Article history

Received

31 March 2017

Received in revised form

6 June 2017

Accepted

30 July 2018

Published online

5 October 2018

*Corresponding author sivarao@utem.edu.my

\section{Graphical abstract}

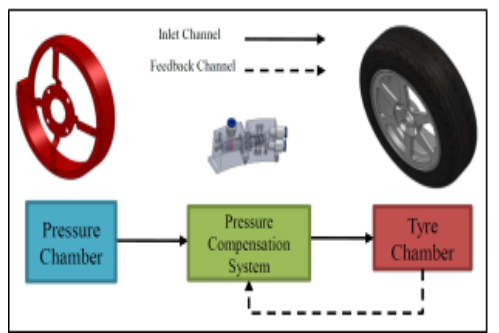

\begin{abstract}
Pneumatic tyres release 10-15 kPa of air pressure every month requires regular topping up. Vehicles run with improper tyre pressure has been identified as one of the primary factors which leads into major and catastrophic road accidents due to puncture and explosion. The main aim of this research work is to design a pressure chamber for an Automatic Tyre Inflating System (ATIS) to replenish the pressure loss of a pneumatic tyre. In this paper, a model has been developed to mathematically derive the critical amount of required pressurized air for ATIS intermediary chamber design. Finite element analysis was also performed onto the designed chamber considering critical engineering elements to ensure safe operation with the pressure of $8449 \mathrm{kPa}$. ATIS is postulated to automatically replenish adequate amount of pressurised air into the tyre when the tyre pressure drops $10 \%$ below the desired pressure. Thus, the air loss from the tyre can be continuously compensated for 12 months to have them running with safe pressure at all time without having human intervention to inflate them.
\end{abstract}

Keywords: Tyre inflating system, tyre pressure, chamber design, finite element analysis, tyre safety

\begin{abstract}
Abstrak
Tayar pneumatik lazimnya akan melepaskan tekanan angin sebanyak 10-15 kPa sebulan. Antara faktor utama yang dikenal pasti dalam menyumbang kepada kemalangan jalan raya serius dan major adalah disebabkan oleh tayar bocor atau meletup. Tujuan utama penyelidikan ini dilakukan adalah bagi mereka bentuk satu kebuk tekanan yang diintegrasikan kepada sistem pengisi angin automatik (ATIS) yang mampu mengisi angin bila mana berlaku kejatuhan tekanan dalam tayar. Satu model matematik telah dibangunkan bagi meramal keperluan tekanan angin bagi kebuk tersebut. Kajian menggunakan model unsur terhingga juga turut dilakukan dengan mengambil kira faktor kejuruteraan bagi memastikan pengoperasian kebuk yang selamat pada tekanan 8449 $\mathrm{kPa}$. Sebaik angin dalam tayar jatuh $10 \%$ di bawah paras yang diperlukan, ATIS akan mengepam angin ke dalam tayar secara automatik. Pembagunan ATIS tidak lagi memerlukan intervansi manusia untuk menyemak dan mengepam tayar secara manual untuk tempoh 12 bulan. Pengepaman automatik ini boleh dilakukan ATIS sama ada kenderaan berada dalam keadaan statik ataupun dinamik kerana kebuk tersebut dipasang terus pada hab rodanya sendiri.
\end{abstract}

Kata kunci: Sistem pengepam tayar, tekanan tayar, rekabentuk kebuk, model unsur terhingga, keselamatan tayar

(C) 2018 Penerbit UTM Press. All rights reserved 


\subsection{INTRODUCTION}

Having tyres properly inflated stand bring advantages to the vehicle owner as it enhances tyre lifetime and promotes a safe driving condition. The main factor of loss control crashes is speed and underinflated tyre. When the tyre pressure is low, it requires a greater steering angle to generate the same cornering force in a curve [1]. A special investigation has been carried out by an agency in United States of America, department of transportation using Goodyear tyres, where effect of tyre pressure was related to the car speed which skidding occurs. Findings summarized that, tyres with 207, 186 and $138 \mathrm{kPa}$ were found started to skid at the speed of $61,59.5$ and $56.3 \mathrm{~km} / \mathrm{h}$ respectively. The investigations also reveal that, car running with lower tyre pressure skids at much lower driving speed [2].

The agency has also performed several other tests using 2001 Toyota 4-runner automobile. It was run through at $80.5 \mathrm{~km} / \mathrm{h}$ at constant speed/decreasing radius circle to see the effects of the inflated pressure on lateral road condition. It was concluded that much lower tyre pressure has proportional lower lateral gforce. The more lateral $g$-force the vehicle utilizes, the better it stays track on the road[3,4]. Lower pressure causes the wheel radius to turn smaller, which alternately increases the speed of the wheel. On the other hand, higher speed relates to higher fuel consumption. It means that the underinflated tyre will use more fuel in comparison to the proper inflated tyre in the same vehicle moving at the same speed[5]. Goodyear indicates that fuel efficiency is reduced by one percentage for every $20.4 \mathrm{kPa}$ of under inflation. The findings also put to the fact that, in case of accident, the record shows the blowout to the front tyre would cause roadway departure, which would also lead to lane change resulting in a head-on crash. Alternately, blowouts of a rear tyre could lead to spinning out and loss of control [6,7]. Puncture is the most common reason for a blowout, where, rapid pressure decrease in the remaining core is often associated with the loss of tyre tread which drastically increases the risk for a vehicle to roll over [8].

Tyre wear at the outer tread area usually results from tyres running consistently in under inflated condition. When a tyre is running with under inflated condition, there would be too much contact with the road by the outer treads and this causes pre-mature wear-off which causes the tyre to fail due to high builtup temperature [9]. When tyres are underinflated, the shape of the tyre footprint and its pressure exertion mechanics onto the road surface would both be altered very much out of what it is supposed to be with proper pressure $[10,11]$. This phenomenon degrades the tyre ability to transmit braking force to the road surface which increases the chance for undesirable stopping distance either in the form of rolling or skidding.
Losing pressure in tyres is a common phenomenon which occurs due to its natural air escapism from properly inflated tyre. Air molecules are very small. Though rubber looks very solid, at the microscopic level, it is a sort of tangled fishnet-like mass of long, stringy molecules. Over time, air molecules can make their way through the maze of molecular chains and escape to the atmospheric. Basically, majority percentage of them would go through the sidewalls as shown in Figure 1.

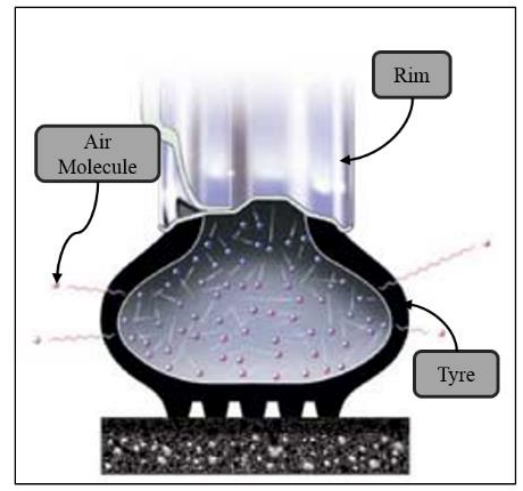

Figure 1 Air molecules escapism through tyre side walls [7]

Air molecules are too tiny. Besides, if the surfaces of the bead and wheel are not clean, or if the wheel is corroded, or if the mounting lubricant does not coat the bead and wheel properly, it is highly possible for air molecules to sneak through the tyre materials as shown in Figure 2 [7]. Since tyres are made of rubber which is a form of porous material, it literally shows that even properly fitted tubeless tyres which are free of mechanical leaks can still have significant pressure loss via permeation as stated by [12]. There is no way to manufacture a tyre that can absolutely hold tight the pressure in it forever.

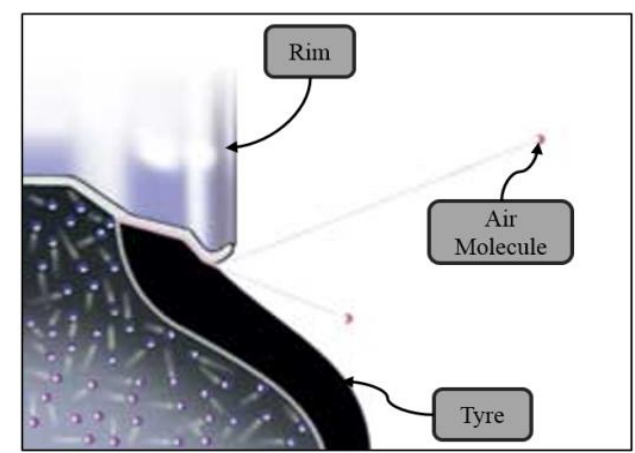

Figure 2 Air molecules sneaks through tyre bead [7]

Another tyre air permeation contributing factors are the temperature (excessive tyre operating heat), and the existence of oxygen in compressed air properties while inflating tyre [13]. On average, 
automobile tyre would lose one to two psi of air per month in cool climate and more upon warmer months due to the way of the air flows, responding to different temperature as claimed by [7]. While the tyre is in operating, it is subjected to cyclic deformations generating possible hysteresis to the spinning tyre as stated by [14] and the energy loss due to this phenomenon influences the friction coefficient and consequently the tyre temperature as claimed by [15]. Therefore, the heat is generated from the result of friction with the road surface, when the rubber structure is under deformation which significantly increase the tyre temperature [16]. As heat increases due to the increase of tyre sidewall flexing, it will slightly more than proportional increase the tyre permeability and porosity [17]. Therefore, a hot tyre is more permeable and tend to experience pressure loses more rapidly as declared by [13]. Besides, heat is accumulated inside the tyre upon overloading towards the tyre, especially during high speed rolling. On a continuous driving, the tyre will reach its parallel state as the increase in temperature will stop upon attaining "Saturation Temperature". In fact,the maximum limit temperature inside tyre is $125^{\circ} \mathrm{C}$ and upon ten minute of tyre rest, the temperature will decrease gradually by about $20^{\circ} \mathrm{C}$ as revealed by [18]. The primary objective of this investigation is to establish a mathematical model which is able to contribute in developing a specially designed pressure vessel to compensate natural pressure loss of a pnematic tyre.

\subsection{METHODOLOGY}

In this paper, the loss of tyres pressure have been investigated by two different operational settings. The first one was unloaded tyre setup where rim was assembled with a brand new tyre and valve stem, mounted on a test rig as shown in Figure 3. The tyre was inflated to $250 \mathrm{kPa}$ and kept remain static for five months without any load being applied. It was kept at room temperature $\left(25^{\circ} \mathrm{C}\right)$ in a closed and controlled room environment. The tyre pressure was measured and recorded monthly using a reliable pressure gauge. This test was conducted for five months continuously without replenishing the tyre.

The similar tyres were also tested in a loaded and operational situations to analyse the pressure drop in both conditions. Loaded tyre setup has been done by mounting the tyre to the actual passenger car, Proton Perdana V6, 2 litre engine - a Malaysian made car, weighing $1000 \mathrm{~kg}$ as shown in Figure 4. The tyre was inflated with compressed air for $230 \mathrm{kPa}$ to operate with the car [19]. Since tyre can lose pressure in both conditions at different rate, so it has been essential to execute the test for both conditions. The specifications of the tyres used for both conditions were from the same brand and new with the profile of 205/55R 16 .

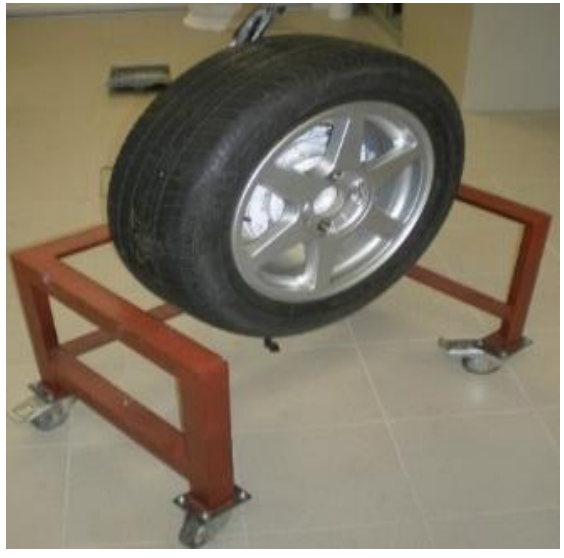

Figure 3 Unloaded condition tyre test setup

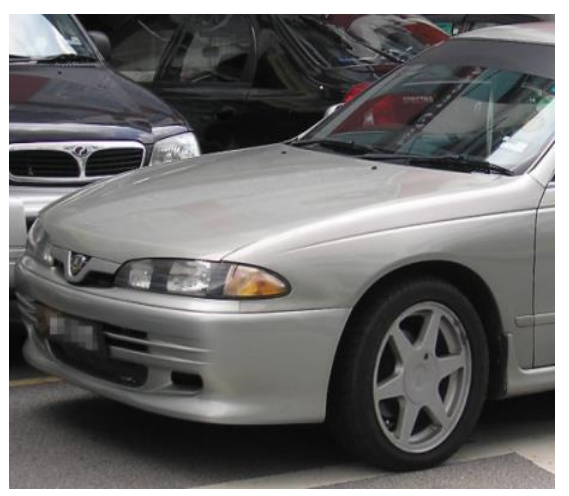

Figure 4 Loaded condition tyre test setup

\subsection{Pressure Compensation Concept}

Looking into the natural phenomenon of air leak from the tyre which may also accidentally lead into major road accidents if tyre is not taken care regularly, a team of researches has concluded to conceptualize a system which could replenish the air loss from a tyre of car being used without any human intervention. Compensation Process is designed to take place where, pressure chamber supply the pressurized air from the pressurised chamber in order to compensate the loss air which resulted into pressure drop of the said tyre. Figure 5 shows the air flow design-schematic for the automatic tyre inflating system. Pressure chamber/chamber stored with high pressure air would supply air accordingly via pressure compensation system. Feedback channel will trigger the pressure compensation system to inflate the tyre whenever the pressure inside the tyre chamber drops below preset/safe operational value.

\subsection{Mathematical Approach}

In this paper, comprehensive illustrations are made to show how a mathematical model was established to determine appropriate pressure value for the pressure 
chamber to cater the pressure losses for at least 12 months (one year) without the need of any manual inflation even to the chamber, far more the tyre. This brings to the conclusion of which, within this interval the automatic tyre inflating system will experience pressure compensating job with sufficient air supply from the pressure chamber before the pressure value for the chamber drops and meets equilibrium state between the pressure and tyre chamber respectively. The ideal gas law equation was applied to identify the required compensation amount to inflate the tyre chamber properly to its safe pre-set pressure value.

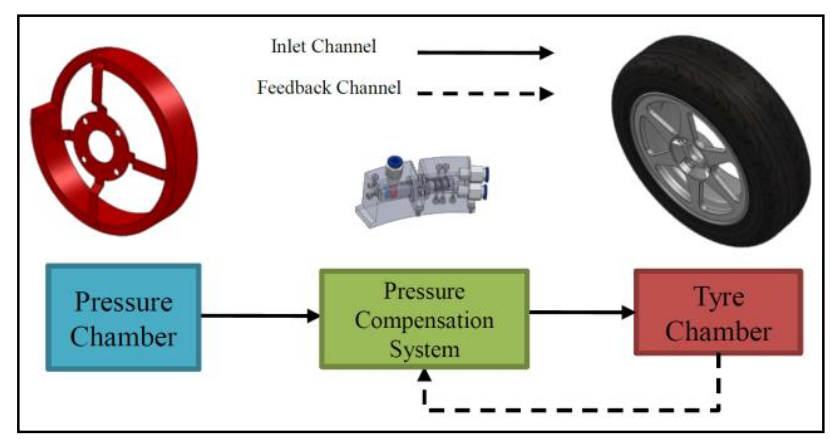

Figure 5 Air flow design schematic for automatic tyre inflation system

The Ideal gas law is as followed;

$\mathrm{PV}=\mathrm{nRT}$

Where:

- $\quad P$ is the pressure of the gas

- $\quad V$ is the volume of the gas

- $\mathrm{n}$ is the amount of substance of gas (also known as number of moles)

- $\quad \mathrm{R}$ is the ideal, or universal, gas constant, equal to the product of the Boltzmann constant and the Avogadro constant.

- $\quad T$ is the temperature of the gas

The gas constant value as followed:

$$
R=8.3145 \frac{\mathrm{J}}{\mathrm{mol} \cdot \mathrm{K}}
$$

Based on ideal gas low, the equation (1) can be written as followed:

$$
\frac{P_{1} \cdot V_{1}}{n_{1} \cdot T_{1}}=\frac{P_{2} \cdot V_{2}}{n_{2} \cdot T_{2}}
$$

Since the volume (V) of the tyre chambers remain the same. The equation (2) can be written as followed:

$$
\frac{P_{1}}{n_{1} \cdot T_{1}}=\frac{P_{2}}{n_{2} \cdot T_{2}}
$$

The main objective of this research is to develop equation that represents the relation between pressure reductions towards time. It is proven that the tyre chamber losses 3kPa monthly as shown in Figure 5. The main purpose of the compensation system is to inflate the tyre chamber whenever the pressure drop below pre-set value. In this case the pre-set value is $230 \mathrm{kPa}$. This preset value will be use as $P_{1 \text { tyre value and }}$ by using it the $\mathrm{n}_{\text {1tyre }}$ can be obtained as followed:

$$
n_{1 \text { tyre }}=\frac{P_{1 \text { tyre }} \cdot V_{1 \text { tyre }}}{R \cdot T_{1 \text { tyre }}}
$$

Where:

$$
\begin{aligned}
& T_{1 \text { tyre }}=273.15+25^{\circ} \mathrm{C}=298.15 \mathrm{~K} \\
& P_{1 \text { tyre }}=230 \mathrm{kPa} \\
& R=8.314 \frac{\mathrm{J}}{\mathrm{mol} \cdot \mathrm{K}}
\end{aligned}
$$

The tyre chamber volume $V_{1 \text { tyre }}$ can be obtained by using the tyre cross section measurement as shown in Figure 6 to calculate the volume using as followed:

$$
\begin{aligned}
& V_{1 \text { tyre }}=\left[\pi\left(\frac{D_{1 \text { tyre }}}{2}\right)^{2} \times d_{\text {tyre }}\right]-\left[\pi\left(\frac{D_{\text {ttyre }}}{2}\right)^{2} \times\right. \\
& \left.d_{\text {tyre }}\right]
\end{aligned}
$$

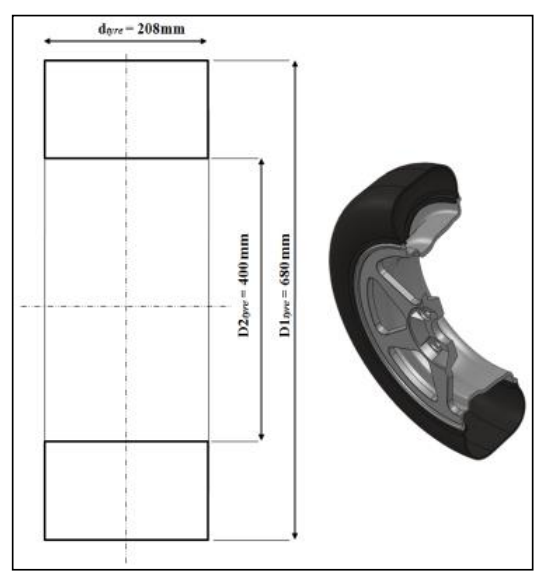

Figure 6 Tyre chamber cross section measurement

With the $V_{1 \text { tyre }}$ obtained,

$$
\begin{gathered}
n_{1 \text { tyre }}=\frac{P_{1 \text { tyre }} \cdot V_{1 \text { tyre }}}{R \cdot T_{1 t y r e}} \\
n_{2 \text { tyre }}=\frac{P_{2 \text { tyre }} \times n_{1 \text { tyre }}}{P_{1 \text { tyre }}}
\end{gathered}
$$


The equation to determine the amount of moles losses for tyre chamber can be calculated as followed;

$$
\Delta n_{\text {tyre }}=n_{1 \text { tyre }}-n_{\text {2tyre }}
$$

The amount of moles transferred $\left(\Delta n_{\text {p.chamber }}\right)$ from the pressure chamber to compensate the tyre chamber losses is equal to meet the equilibrium theory and it can be described as followed;

$$
\Delta n_{\text {p.chamber }}=\Delta n_{\text {tyre }}
$$

The equation (9) can be written as followed;

$$
\begin{aligned}
& \Delta n_{\text {tyre }}=n_{1 \text { p.chamber }}-n_{2 p . \text { chamber }} \\
& \Delta P_{\text {chamber }}=P_{1 \text { p.chamber }}-P_{2 \text { p.chamber }}
\end{aligned}
$$

The pressure chamber volume remains unchanged so,

$$
\begin{gathered}
V_{1 \text {.chamber }}=V_{2 \text {.chamber }}=V_{\text {p.chamber }} \\
V_{1 \text { p.chamber }}=\left[\pi\left(\frac{D_{1 p . c h a m b e r}}{2}\right)^{2} \times\right. \\
\left.d_{\text {p.chamber }}\right]-\left[\pi\left(\frac{D_{2 \text { p.chamber }}}{2}\right)^{2} \times d_{\text {p.chamber }}\right]
\end{gathered}
$$

Just like before, using the pressure chamber cross section measurement as shown in Figure 7, the volume for the pressure chamber $V_{1 p \text {.chamber }}$ can be obtained as followed:

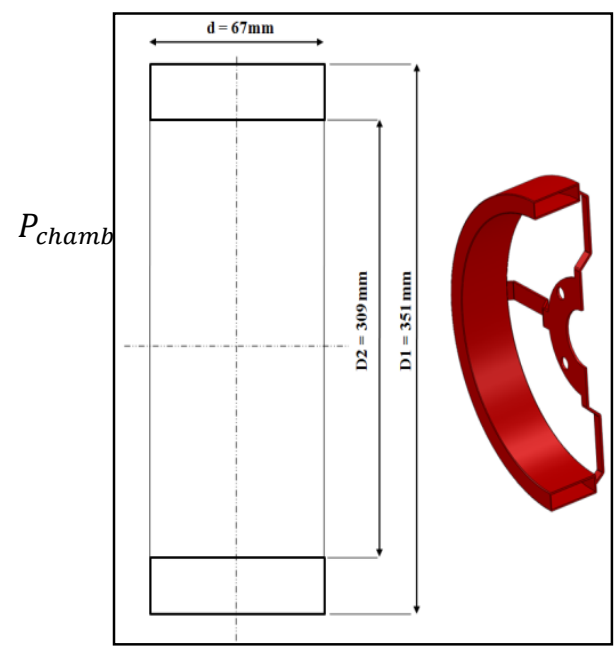

Figure 7 Pressure chamber cross section measurements
If $P_{1 \text { p.chamber }}$ is given as " $350 \mathrm{kPa}$ " (random value)

and $T_{1 p . \text { chamber }}=T_{2 p \text {.chamber }}=298 \mathrm{~K}$, the $P_{2 p \text {.chamber }}$ now can be obtained as followed:

$$
\begin{aligned}
& \left(\frac{P_{2 \text { p.chamber }} \times 1.45867 \times 10^{-3}}{8.314 \times 298}\right)= \\
& \left(\frac{350 \times 10^{3} \times 1.45867 \times 10^{-3}}{8.314 \times 298}\right)-0.06 \mathrm{~mol}
\end{aligned}
$$

Since the changes were linear, the pressure versus time relation for the pressure chamber can be written as followed;

$$
P_{\text {p.chamber }}=y-\frac{\Delta P_{\text {p.chamber }}}{\Delta t_{\text {p.chamber }}} \times t_{\text {p.chamber }}
$$

; y $=$ initial pressure value

$\Delta P_{\text {chamber }}$ can be derived as followed;

$\Delta P_{\text {chamber }}=P_{1 p . c h a m b e r}-P_{2 p . c h a m b e r}$

In this case study $\Delta t_{\text {chamber }}=1$ month meaning,

$$
\begin{gathered}
P_{\text {chamber }}=\frac{101.91}{1} \times t_{\text {chamber }} \\
P_{\text {chamber }}=y-101.91 t_{\text {chamber }}
\end{gathered}
$$

Equation (17) is valid for tyre which undergone unloaded condition, by referring to previous study it was shown that, loaded condition tyre losses more pressure and the ratio was "20:3" in average.

The linear equation for loaded condition can be written as follow:

$P_{\text {chamber }}=y-\left(\frac{20}{3}\right) 101.91 t_{\text {chamber }}$

Based on (17) and (18), amount of pressurized air to be filled inside the pressure chamber can be identify and the result is presented in Figure 8 . It shows that, in an unloaded condition, the pressure chamber is required to be filled with at least $1515 \mathrm{kPa}$ to sufficiently maintain the tyre pressure for approximately 12 months. On the other hand, for the loaded condition, the initial pressure must be at least $8449 \mathrm{kPa}$ to provide sufficient supply for the same duration of time. Once the pressure inside the pressure chamber is dropped to $290 \mathrm{kPa}$, where it would be indicated by colour switch cap, then, refill will be required. As inflating occurs every month, it has been designed that tyre inflating is only required once in a year. 


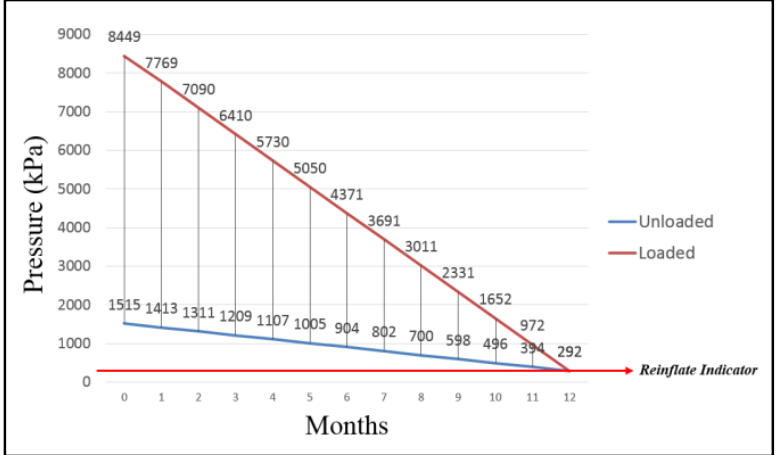

Figure 8 Pressure chamber - pressure losses vs time/duration

\subsection{Finite Element Analysis}

Finite element analysis (FEA) was used to analyse the Factor of Safety (FOS) for the designed structure with commercially available analytical tool called Solidworks. The analysis is capable of presenting stress distribution based on the selected materials of the design. Being the most critical and significant parameter, the temperature obtained from experimental thermal investigation, and the pressure obtained from mathematical model were fed into the analysis. The geometry of pressure capsule chosen for this analysis is the optimized version in terms of materials, engineering specification, operational condition, etc. The pressure capsule will receive pressurized air at the inner wall of the chamber that undergoes great tensile stress. The inner wall pressure subjected from pressurized air inside the chamber. The ultimate aim of the FEA analysis is to ensure the FOS value falls at the range of 1.2 and above. Andreas and Lasn (2014) stated that, normal factor of safety (FOS) of static 80 burst for pressure vessel is at least 1.18 thus the FOS targeted obtained for the pressure capsule was slightly higher than the recommended value which is confirmed to be operationally safe.

Figure 9 and Figure 10 present the finite element analysis and simulation with von Mises stress distribution. The red arrow indicates pressure orientation towards the specific geometry, while the blue arrow represents temperature contact faces, and the green arrow indicates fixed face.

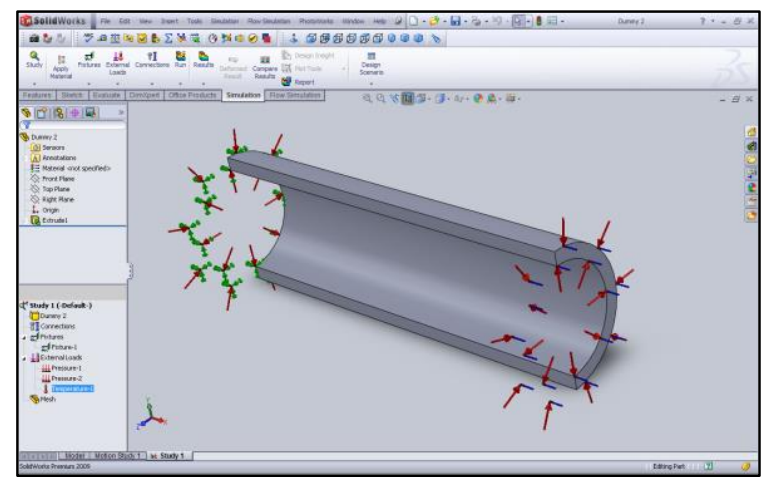

Figure 9 Simulation of Finite Element Analysis

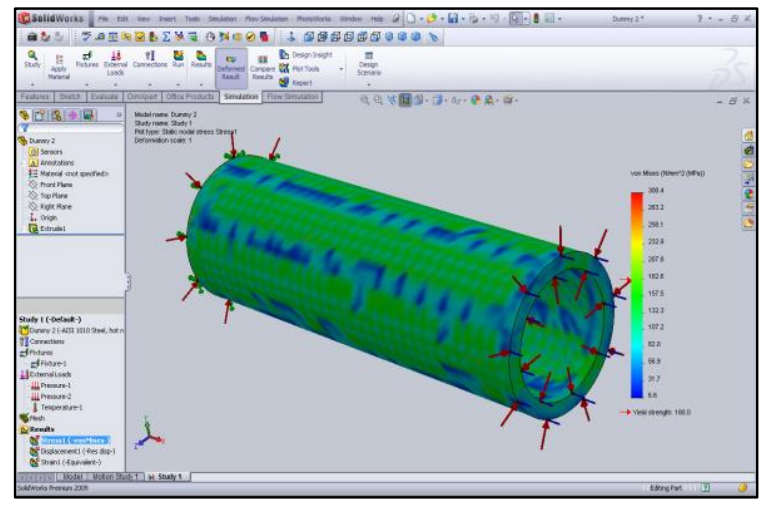

Figure 10 Finite Element Simulation of Von Mises Stress Distribution

\subsection{RESULTS AND DISCUSSION}

The results for both conditions can be seen in Figure 11. Unloaded tyre condition shows that, the tyre experiences pressure drop gradually from October 2013 up to February 2014 in a smaller scale. This shows that tyres experiences pressure drop even at room temperature, without operating and putting additional weight to it in a smaller scale due to air permeation via the existing condition of the tyre materials.

Loaded tyre test setup shows that, the tyre experiences pressure losses gradually from October 2013 up to February 2014 in a larger scale as the vehicle travels more. It is very obvious that the pressure keeps dropping more in a loaded tyre test condition as compared to unloaded tyre test condition. This is mainly the effect of operating temperature and load on the tyre. As the originally inflated pressure decreases, the temperature would keep increasing onto the tyre during operation as the under inflated tyre results in severe deformed profile of the tyre rubber surface. This situation generally increases normal load on a tyre that eventually increases elastic deformation which also increases the total strain energy density results in temperature rise as stated by [18] and therefore, ultimately increases the porosity of 
the tyre providing enough space for severe air leakage to the atmosphere.

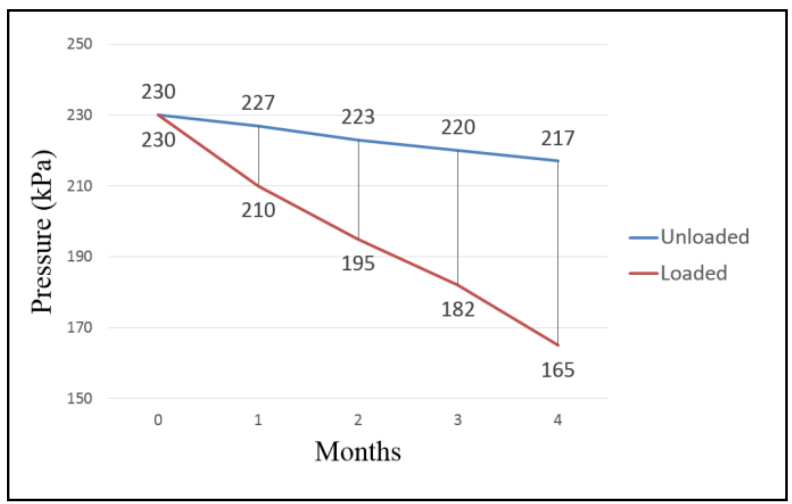

Figure 11 Tyre pressure for loaded and unloaded tyre test

While Figure 12 shows the design of pressure chamber, Figure 13 shows the Finite Element Analysis (FEA) results of the pressure chamber after undergone structural simulation analysis using pre-determined maximum working pressure of $8449 \mathrm{kPa}$. The material used for the simulation was AISI 304 Stainless Steel. By using von misses stress model, the maximum von misses stress value for the analysis on the chamber is $1.717 \mathrm{x}$ $10^{8}$ Pascal where, the materials yield strength $2.068 \mathrm{x}$ $10^{8}$ Pascal so the factor of safety of the chamber was 1.2 which is considered safe according to ASME pressure vessel code. The results indicate that the pressure chamber design structure theoretically manage to contain the maximum working pressure without fail. Based on finite element analysis (FEA) the AISI 304 Stainless steel has been chosen as the pressure chamber material.

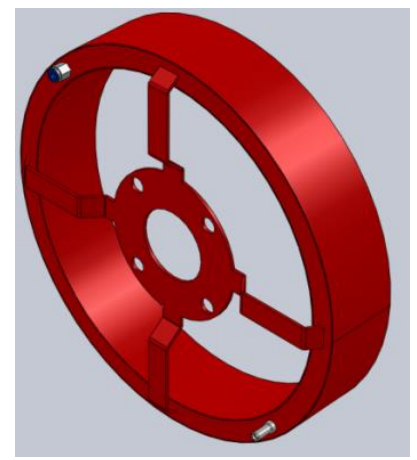

Figure 12 Pressure chamber design for strength analysis

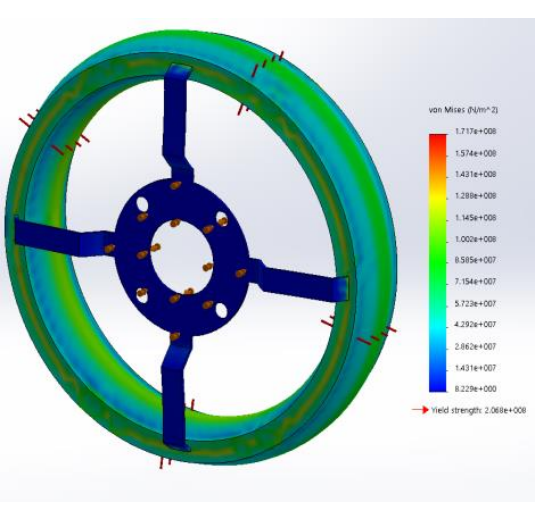

Figure 13 Pressure chamber FEA analysis result

The automatic inflating system comprises of pressure chamber which provided pressurized air supply for the system. Compensation system itself consists of two sub-system which are pressure trigger system and shut off valve system. Compensation system will automatically supply appropriate amount of pressurized air to compensate the pressure losses. Based on the critical conceptual design, the compensation system must be built inside the pressure chamber and this requires a lot of constraint consideration towards the design of compensation system. Figure 14 shows the conceptual system integration between compensation system and pressure chamber.

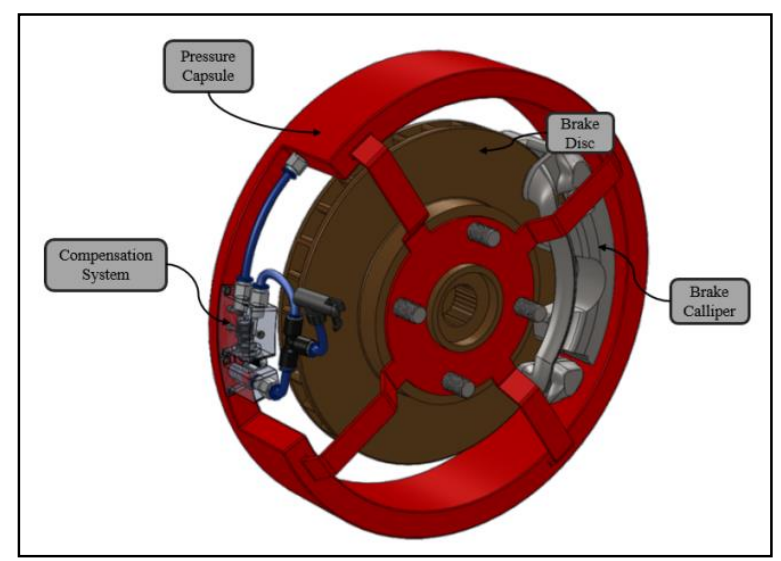

Figure 14 Conceptual of integrating pressure chamber and compensation system

The proposed, conceptualised and designed automatic inflating system is a fully mechanical based system, not even a single electrical component involved. This is essential to keep the system simplified and optimized to ensure it is cost effective and highly reliable. Combination of those two sub-system (pressure trigger and shut off valve) is expected to successfully be formed to the development of compensation system of the device in near future. 
Those two sub-system will be attached to pressure chamber enabled the final assembly of the device. The device then will be assembled together with the wheel of the vehicle. Figure 15 shows final design concept of the said device which was based on $[20,21]$ conceptual design of how it would look like upon development in near future.

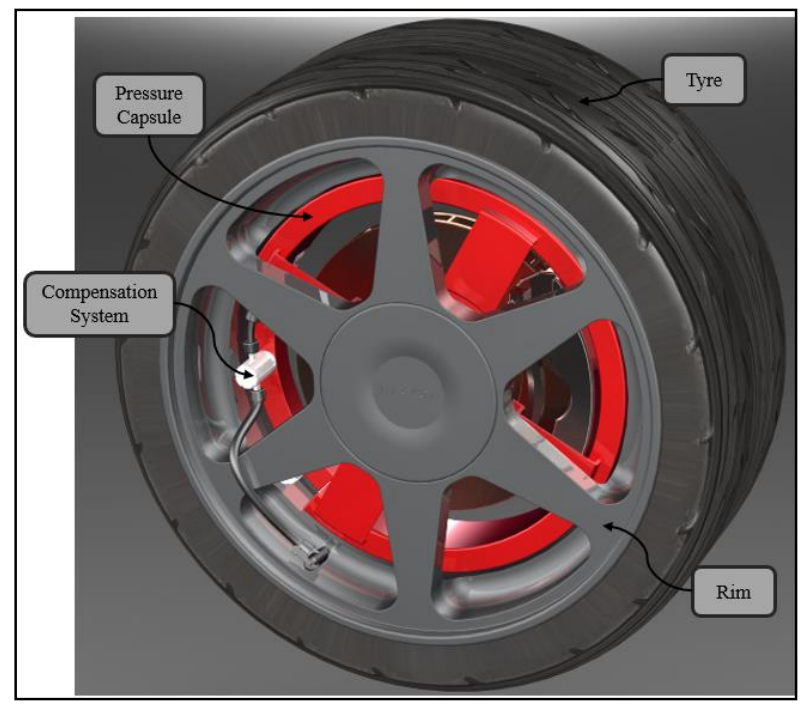

Figure 15 Wheel embedded automatic tyre inflating system

\subsection{CONCLUSIONS}

The ultimate aim of the investigated automatic tyre inflating system is designed to cater middle class automobile users where, this would be a cost effective solution to ease users in maintaining proper tyre pressure for the period of 12 months (a year). The predetermined time interval investigation was established by mathematical modelling and also finite element analysis before it is taken to the safety design stage suiting operational condition. Thus, the compensating device will be able to sustain and maintain the desired tyre pressure up to 12 months period before the re-inflating is required for the pressure chamber. By utilizing this model, variation of pressure chambers can be custom made and developed for particular model of automobile.

\section{Acknowledgements}

The authors/researchers would like to thank the Ministry of Higher Education Malaysia and also Universti Teknikal Malaysia Melaka for awarding High Impact Research Grant Scheme (Grant Number: PJP/2017/FKP/HI15/S01547 in pursuing this research. Special thanks to the Faculty of Manufacturing Engineering, Advanced Manufacturing Centre,
Centre for Research and Innovation Management for their continuous courage and support.

\section{References}

[1] Giulio Reina, Angelo Gentile, Arcangelo Messin. 2015. Tyre Pressure Monitoring Using a Dynamical Model-Based Estimator. Vehicle System Dynamics. 53(4): 568-586.

[2] Vasantharaj A. and K. Krishnamoorthy. 2016. Tire Pressure Monitoring System Using SoC and Low Power Design. Circuits and Systems. 7: 4085-4097.

[3] P. S. Anoop, V. Sugumaran and Hemanth Mithun Praveen. 2016. Implementing K-Star Algorithm to Monitor Tyre Pressure using Extracted Statistical Features from Vertical Wheel Hub Vibrations. Indian Journal of Science and Technology. 9(47): 1-7.

[4] Mr. V. S. Mane, Nutan, N. Bachulkar, Poornima, B. Bargale, Snehal, S. Kole. 2016. Run Time Tire Pressure Monitoring and Controlling System. International Research Journal of Engineering and Technology. 03(02): 1191-1194.

[5] Inderjeet Singh, Bhupendra Pratap Singh, Hari Shankar Sahu, Raunak Chauhan, Novel Kumar Sahu. 2016. To Study on Implementation of Tyre Inflation System for Automotive Vehicles. International Journal of Innovative Research in Science, Engineering and Technology. 5(4): 4708-4711.

[6] Jacek Caban, Paweł Droździel, Dalibor Barta, Štefan Liščák. 2014. Vehicle Tire Pressure Monitoring Systems. Diagnostyka. 15(3): 11-14.

[7] Mika Matilainen, Ari Tuononen. 2015. Tyre Contact Length on Dry and Wet Road Surfaces Measured By Three-Axial Accelerometer. Mechanical Systems and Signal Processing. 52(53): 548-558.

[8] D. P. Willis. 2000. Tire Failure and Tire Blowouts. New York. 2.

[9] Murray. 2014. How to Read Tire Wear. Available at: http://www.murraystirebargains .com/shared/ content/Library / encyclopaedia/ ch25/25 readtirewear.html, accessed May.

[10] Tawanda Mushiri, Allan, T. Muzhanje, Charles, Mbohwa. 2016. Design of an Automatic Tyre Pressure Inflation System for Small Vehicles. International Conference on Industrial Engineering and Operations Management Detroit. Michigan, USA. 23-25 September 2016.

[11] Maryam Norouznejad Jelodar, Bahram Azizollah Ganji. 2016. Design and Analysis of Novel MEMS Capacitive Ttire Pressure Sensor with High Sensitivity and Linearity. Majlesi Journal of Telecommunication Devices. 5(2): 70-75.

[12] Coddington, D. M. 1979. Inflation Pressure Loss in Tubeless Tyres-Effects of Tyre Size, Service, and Construction. Rubber Chem. Technol. 52(5): 905-919.

[13] Brian Basch. 2011. The Past, Present and Future of Nitrogen Tire Inflation, Real World Application and Acceptance of Nitrogen Commercial Success from Passenger to Commercial Markets. Branick Industries. 3-13.

[14] Farroni, F., E. Rocca, and F. Timpone. 2013. A Full Scale Test Rig to Characterize Pneumatic Tyre Mechanical Behaviour. International Review of Mechanical Engineering. 7.

[15] Allouis, C., A. Amoresano, D. Giordano, M. Russo, and F. Timpone. 2012. Measurement of the Thermal Diffusivity of a Tire Compound by Mean of Infrared Optical Technique. International Review of Mechanical Engineering. 6: 11041108.

[16] Abdullah, M. A., N. Tamaldin, M. Khatib, A. Aziz, and A. Fadhli. 2013. Increasing the Tire Life Span by Means of Water Cooling. International Journal of Mining, Metallurgy \& Mechanical Engineering. 1: 78-80.

[17] Paul, W. Macdermid, Matthew, C. Miller, Fiona, M. Macdermid, and Philip, W. Fink. 2015. Tyre Volume and Pressure Effects on Impact Attenuation during Mountain Bike Riding. Shock and Vibration. 2015: 1-10. 
[18] Fabienne Anfosso-Le'de'e, Yves Pichaud. 2007. Temperature Effect on Tyre-Road Noise. Applied Acoustics. 68: 1-16.

[19] Sivaraos and D. Ainol. 2010. Tire Inflation Technology Existing And An Evolution To Be: Advancements In Tire Inflating Technology, Lambert, Germany. 3-5.

[20] Tang. T, D. Johnson, R. E. Smith, and S. D. Felicelli. 2014. Numerical Evaluation of the Temperature Field of Steady-
State Rolling Tires. Applied Mathematical Modelling. 38: 1622-1637.

[21] Ainol Suhada Dahlan. 2016. Automatic Tyre Pressure Replenishing System Development Assisted By Mathematical Modelling and Finite Element Analysis. PhD Thesis, UteM. 